\begin{tabular}{|l|c|c|c|r|}
\hline $\begin{array}{l}\text { Cuadernos de Investigación Geográfica } \\
\text { Geographical Research Letters }\end{array}$ & 2018 & N $^{\circ} 44(2)$ & pp. 719-742 & $\begin{array}{r}\text { ISSN 0211-6820 } \\
\text { eISSN 1697-9540 }\end{array}$ \\
\hline
\end{tabular}

DOI: http://doi.org/10.18172/cig.3371

(C) Universidad de La Rioja

\title{
RAINFALL EXTREMES MODELING UNDER SHORTAGE OF DATA AND UNCERTAINTY IN THE PAMPEAN REGION (ARGENTINA)
}

\section{PURICELLI}

Instituto Nacional de Tecnología Agropecuaria, Estación Experimental Balcarce, Ruta 226, Km 73.5, (7620), Balcarce, Provincia de Buenos Aires, Argentina.

\begin{abstract}
The assessment of the surface runoff capacity of storms is essential for the design of drainage infrastructure, for the management of rainfall excesses and the control of soil erosion. The knowledge of precipitation intensity values at scales larger than the daily is a key in this process. However, the available information in the region is reduced, due to the lack of instruments and historical data. An alternative to solve this problem consists of the search of mathematical relations for the scale change from daily values, more common and available, to sub-hourly values, necessary for the estimation of runoff volumes in small basins as well as erosive power of rainfall. The first results obtained in the experimentation and search of mathematical relations for the change of temporal scale for values of intensity of precipitation, valid for a wide territory with clear climatic and ecological variability are presented in this paper. The main objective of this work was to investigate the property of scale invariance in rainfall intensity and its application to the construction of IDF curves by simple scaling. The regionalization of the values obtained in the areas of study was established as a complementary objective. The hypothesis of the scale invariance and the possibility of applying simple scaling to precipitation intensity values have been verified using both pluviographic and pluviometric data recorded over the Argentina's Pampean region in climatically and ecologically different localities. The present work provides the criteria and reference values for the construction and updating of the IDF curves in the region, where they are highly necessary, leading to advances in hydrology in areas with little or no rainfall information. The results provide new evidence on scaling relations in hydrological variables, which are useful for application in cases where reference information is scarce. This contributes to the knowledge of local precipitation characteristics and provides reference values to be used in practical applications.
\end{abstract}

Modelado de precipitaciones extremas bajo escasez de datos e incertidumbre en la región pampeana (Argentina)

RESUMEN. La evaluación de la capacidad de escorrentía superficial de las tormentas es esencial para el diseño de la infraestructura de drenaje, para el manejo de los excesos de lluvias y el control de la erosión del suelo. El cono- 
cimiento de los valores de intensidad de precipitación a escalas mayores que el diario es una clave en este proceso. Sin embargo, la información disponible en la región se reduce, debido a la falta de instrumentos y datos históricos. Una alternativa para solucionar este problema consiste en la búsqueda de relaciones matemáticas para el cambio de escala de valores diarios, más comunes y disponibles, a valores sub-horarios, necesarios para la estimación de los volúmenes de escorrentía en pequeñas cuencas así como el poder erosivo de la precipitación. Se presentan los primeros resultados obtenidos en la experimentación y búsqueda de relaciones matemáticas para el cambio de escala temporal para valores de intensidad de precipitación, válidos para un amplio territorio con clara variabilidad climática y ecológica. El objetivo principal de este trabajo fue investigar la propiedad de la invariancia de la escala en la intensidad de la lluvia y su aplicación a la construcción de las curvas IDF mediante escalamiento simple. La regionalización de los valores obtenidos en las áreas de estudio se estableció como un objetivo complementario. La hipótesis de invariancia de escala y la posibilidad de aplicar escala simple a valores de intensidad de precipitación se han verificado utilizando datos pluviométricos y pluviográficos registrados en la Región Pampeana argentina en localidades climáticamente y ecológicamente diferentes. El presente trabajo proporciona los criterios y valores de referencia para la construcción y actualización de las curvas de las IDF en la región, donde son altamente necesarios, lo que conduce a avances en hidrología en áreas con escasa o nula información sobre las precipitaciones. Los resultados aportan nuevas pruebas sobre las relaciones de escala en variables hidrológicas, de utilidad para su aplicación en casos en que la información de referencia es escasa. Esto contribuye al conocimiento de las características de precipitación local y proporciona valores de referencia que se utilizarán en aplicaciones prácticas.

Key words: rainfall intensity, scale invariance, simple scaling, Pampa, Argentina.

Palabras clave: intensidad de precipitación, invariancia de escala, escalado simple, Pampa, Argentina.

* Corresponding author: Marino Puricelli, Instituto Nacional de Tecnología Agropecuaria, Estación Experimental Balcarce, Ruta 226, Km 73.5, (7620), Balcarce, Provincia de Buenos Aires, Argentina. E-Mail address: puricelli.marino@inta.gov.ar

\section{Introduction}

Climatic events as a whole are receiving increasing attention due to the loss of human lives as well as the exponential increase in the material damage they cause (Karl and Easterling, 1999). Maximum rainfall extremes are defined as those episodes of rainfall above a certain threshold value which is close to the historical maximum observed value (Chow et al., 1994; IPCC, 2012). Several authors (Kunkel et al., 1999; Easterling et al., 
2000) have emphasized that society as a whole has become progressively more vulnerable to such events. However, due to their low frequency of historical occurrence, they tend to be forgotten until a new event takes place, exposing society to its vulnerability and impelling it to overcome the barriers that prevent its adaptation (Davison and Wong, 2005; Travis, 2014). This process requires the development of up-to-date and reliable local information for the hydrological design of structures and territorial planning strategies.

The Intensity-Duration-Frequency curves (hereafter IDF curves) provide the information necessary for the design of works for flood dampening and runoff drainage caused by extreme rainfall events in urban and rural areas (Chow et al., 1994; Menabde et al., 1999; van Dijk, 2002; Schindewolf and Schmidt, 2012).

The approach for the generation and analysis of this information is probabilistic, since natural processes are not purely deterministic (Yevyevich, 1972). The IDF curves represent the relationship between the values of maximum precipitation intensity corresponding to a reference duration and the associated return time (Chow et al., 1994). They are essentially a family of curves, each of which represents the cumulative frequency distribution function of annual maximum precipitation intensity, for different values of rain duration (Sivapalan and Blöschl, 1998). Its general form was proposed by Koutsoyiannis et al. (1998) and is represented in Eq. (1), where $i$ is the precipitation intensity, $a(T)$ is a function of the distribution probability of an extreme event of intensity for a return time $T$, and $b(d)$ is a function of the duration $d$.

$$
i=\frac{a(T)}{b(d)}
$$

The construction of IDF curves involves both information and scale issues. Generally, the pluviographic records are limited both in the number of observation points and in the volume of historical data available (Di Leo et al., 1999; Gabriels, 2006). This situation causes errors that reduce the precision of the statistical estimators of the population of data analyzed (USGS, 1982; Rojas and Conde, 1985; Bougadis and Adamowsky, 2006). Scale issues arise because of the nature of the phenomenon and human limitations for observation and modeling because storms, along with the other hydrological phenomena, cover a wide range of characteristic scales (Blöschl and Sivapalan, 1995; Pavlopoulos and Gupta, 2003; Gebremichael et al., 2006; Panthou et al., 2014). Thus, while the prediction of its behavior and the design of scenarios requires the validation of models along the range (Wood, 2011), the measurements occupy a reduced space-time window of the same (Klemeš, 1983; Zhou et al., 2006; Gentine et al., 2012).

In Argentina, pluviometric information is much more extensive and continuous in time than pluviography (Rojas and Conde, 1985). Scaling, the transformation of information along several scales (Blöschl and Sivapalan, 1995), is an alternative to fill the gap between the available information and the description of the phenomenon at different scales (Zhou et al., 2006). This property is based on the hypothesis of the 
existence of scale invariance, by which the process behaves similarly at different scales (Lovejoy and Schertzer, 1985).

Different authors have shown that scale invariance is an inherent feature of water processes (Lovejoy and Schertzer, 1985; Gupta and Waymire, 1987; Bougadis and Adamowsky, 2006; Rodríguez-Iturbe and Rinaldo, 1997; Langousis et al., 2009; Blanchet et al., 2016).

Particularly, the concepts of scale, scalability and scale invariance have been applied in the modeling and analysis of rainfall data (Gupta and Waymire, 1990; Burlando and Rosso, 1996; Kuzuha et al., 2005). Yu et al. (2004) propose that the scaling of rainfall intensity $i$ for a duration $d$ can be expressed by Eq. (2) where the equality sign indicates that the probability distributions are identical to both sides of the equation, $d / D$ is the scale relation between unknown and known duration and $\lambda$ is the scaling factor. This type of behavior was termed as "strict sense simple scaling" by Gupta and Waymire (1990).

$$
i_{d}=\left(\frac{d}{D}\right)^{\lambda} i_{D}
$$

The scale invariance hypothesis in Equation (2) can be empirically verified by means of the statistical moment scaling method (Sivakumar, 2000). If accepted, it is possible to derive the value of $\lambda$, and construct models for practical use. For this purpose, Yu et al. (2004) indicate that Equation 2 can be rewritten in terms of the statistical moments of order $q$, for each duration $d$ (Equation 3).

$$
E\left[i_{d}^{q}\right]=\left(\frac{d}{D}\right)^{\lambda} E\left[i_{D}^{q}\right]
$$

Under this hypothesis, Equation (4) shows that the value of $\lambda$ is the slope of the line of the logarithmic transformation of Equation (3) (Yu et al, 2004).

$$
\log E\left[i_{d}^{q}=\right] \lambda \log \left(\frac{d}{D}\right)+\log E\left[i_{D}^{q}\right]
$$

Pappenberger and Beven (2006) point out theoretical and practical reasons for the inclusion of uncertainty in hydrological analyses. In the case of rainfall intensity, uncertainty is traditionally considered during the frequency analysis, but rarely in the later stage of curve design, provoking risks underestimation (Overeem et al., 2008). It should be considered that the available data of precipitation intensity covers only a limited time window, so assuming uncertainty becomes relevant (Van de Vyver and Demarée, 2010). One of the ways proposed to include it in the IDF curves is the generation of quantile intensity for different time values using some statistical method of simulation and develop a confidence interval for each IDF curve (Overeem et al., 2008; Van de Vyver and Demarée, 2010).

The regional analysis allows the extension of the point results to the whole of a geographical area (Bocciola et al., 2003; Szolgay et al., 2009). Regionalization represents a necessary and transcendent step towards hydrological prediction of basins without data (Sivapalan, 2003; Vogel, 2005). In the case of the IDF curves various authors such as 
Durrans and Kirby (2004), Blanchet et al. (2016), Paixao et al. (2011), Jiang and Tung (2013), Hailegeorgis et al. (2013) have reported advances in this issue.

The Pampean region (Fig. 1) is a large area of Argentina, occupying 19\% of its national territory, owns $64 \%$ of the total population of the country. Most of the region is located within the Del Plata basin, integrated by the rivers Paraná, Paraguay, Uruguay and the Río de la Plata, which covers approximately 3.2 million $\mathrm{Km}^{2}$, in Argentina, Bolivia, Brazil, Paraguay and Uruguay. Affected by a wide rainfall variability (Aliaga $e t$ $a l ., 2016)$, the dominant landscape is plain and it soils, mainly devoted to agriculture and livestock are affected by water erosion processes by $25 \%$ (Casas, 2015).

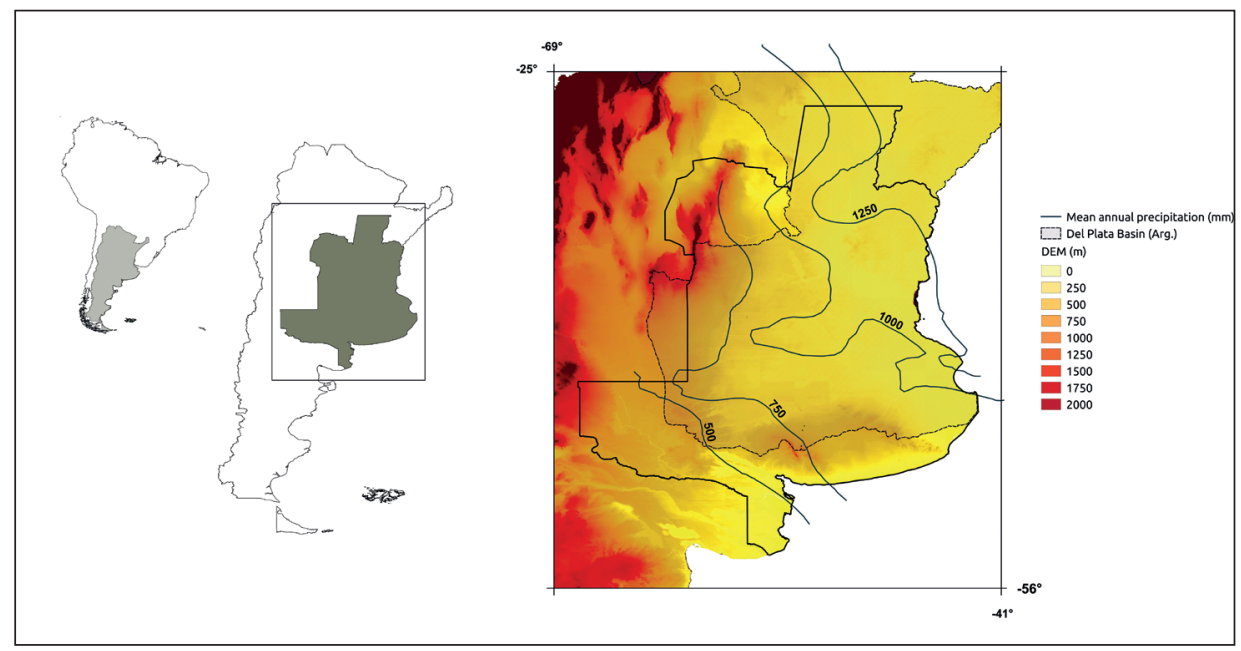

Figure 1. Pampean region. DEM, del Plata Basin limits, and rainfall distribution.

There is a strong need of IDF curves for the development of civil works and prevention of water erosion in this region. However, the scarcity of updated rainfall information, not only in the amount of data but also in the spatial distribution of measurement points, and the few available IDF curves strongly limits the possibilities of development. In this context, the combination of pluviometric and pluviographic information through simple scaling, would allow IDF curves in the region for the design and updating of water and hydraulic works in rural, peri-urban and urban environments.

There is a lack of information in the Pampean region regarding the application of simple scaling in the construction of IDF curves. Mauriño (2004) and Zamanillo et al. (2008) shows IDF curves estimated by conventional empirical procedures (GarcíaBartual and Schneider, 2001). Outside the Pampas region, Nagettini (2012) applied the model proposed by Menabde et al. (1999) for an area at the south of Brazil, and Burgos et al. (2015) applied the simple scaling model proposed by Yu et al. (2004) for two basins located in the province of Catamarca (Argentina). There have been no advanced studies in the analysis of uncertainty or regionalization based on the estimated points using this technique, in none of the cases. 
The main objective of this work was to investigate the property of scale invariance in the rain intensity and its application in the construction of IDF curves by simple scaling. Complementarily, it was established as objective the regionalization of the values obtained in the areas of study.

\section{Data and methods}

For the present study, a total of 22 locations were analyzed (Fig. 2), in five of which rainfall and pluviometric data were collected. In the remaining 14 , only previous IDF curves were available.

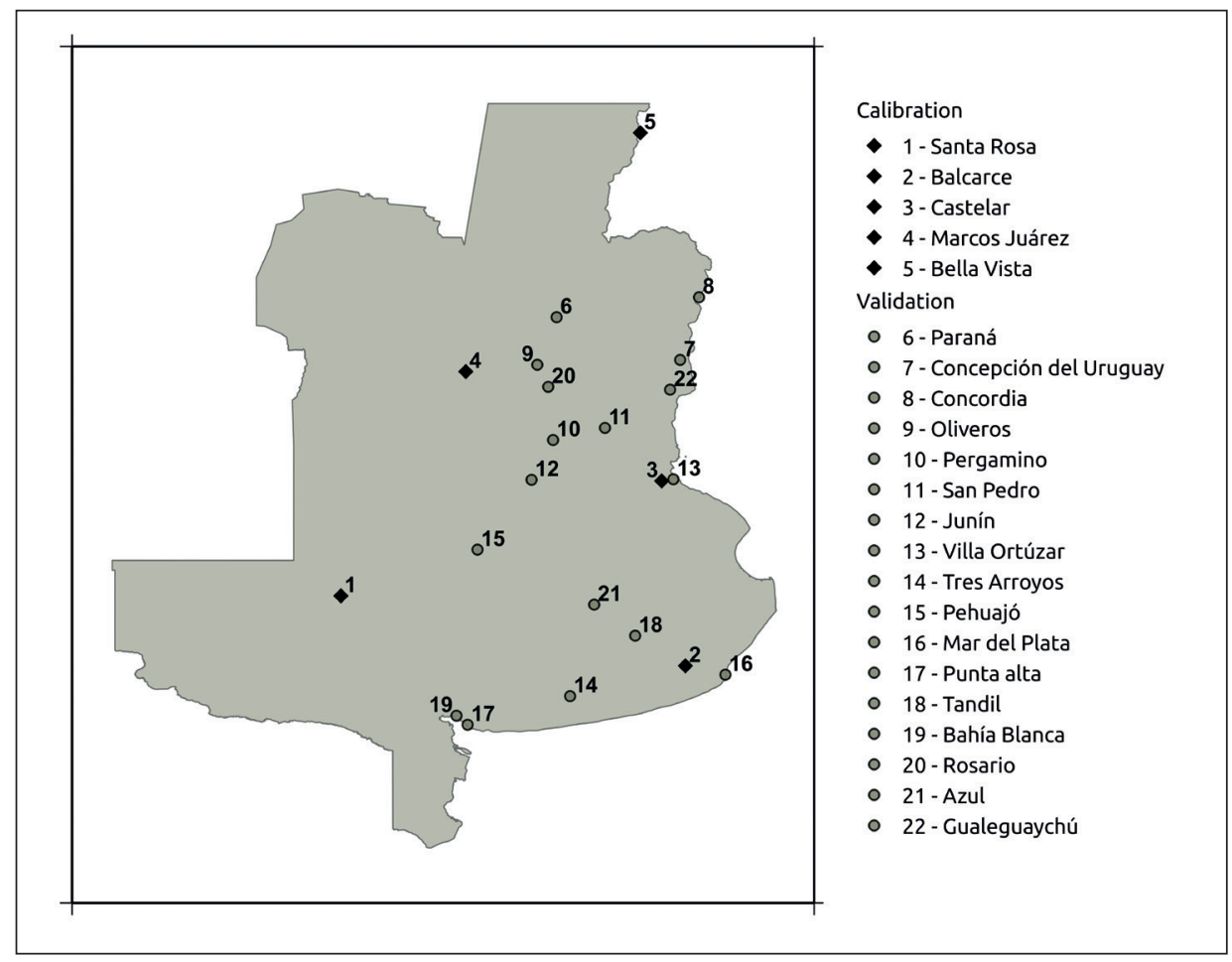

Figure 2. Locations analyzed at work. Locations used in calibration (diamonds) and regional analysis (circles).

The selected locations for the analysis of the scale invariance and simple scaling are those in which rainfall intensity crude data series was found: Santa Rosa, Balcarce, Castelar, Marcos Juárez, and Bella Vista. They cover a wide range of rainfall regimes. According to the classification criteria of the pluviometric regime in the Pampean region proposed by Aliaga et al. (2016). Santa Rosa (SE) corresponds to the "dry" regime, while Bella Vista (NE) is classified as "extremely wet". Likewise, distribution patterns of precipitation intensity vary in the Pampean region preponderantly from SW to NE. 
The events with maximum daily precipitation intensity achieved greater coverage in the region between October and April, with maximums between the Argentine NE and S of Paraguay (Robledo and Penalba, 2008).

The locations analyzed belongs to different ecoregions (Buckart et al., 1999): Pampas (Balcarce, Castelar, Marcos Juárez), Espinal (Santa Rosa) and Esteros de Iberá (Bella Vista). Data come from different meteorological records. In the case of Santa Rosa, from the Faculty of Agronomy of the National University of La Pampa meteorological records, while Balcarce, Castelar, Marcos Juárez and Bella Vista by the National Institute of Agricultural Technology (INTA).

For each location $i$, the data corresponding to an amount $n$ of $j$ years, corresponding to different time intervals, were accounted. In the case of Santa Rosa it was of 10 years (between 2005 and 2014), for Balcarce of 16 years (between 1991 and 2006), for Marcos Juárez was of 20 years (between 1995 and 2014), for Castelar of 21 years 1990 and 2010) and for Bella Vista of 17 years (between 1992 and 2008). Records of intensity of annual maximum precipitation corresponding to $d$ periods varying between 30 and 1440 minutes were recorded for each year, except for Santa Rosa, which varied from 5 to 1440 minutes.

A quality control of data was performed to ensure the quality of the information analyzed (González Rouco et al., 2001). The pluviometric series were analyzed. For the rainfall intensity data, the maximum annual intensity series selected were analyzed for each duration $d$. First, the pluviometric and rainfall intensity data series were subjected to an exploratory data analysis, using graphs to explore, understand and present data, to ensure the absence of missing data, inconsistencies or errors. Next, the pluviometric series were subjected to a homogeneity analysis (Kundzewicz and Robson, 2004, González Rouco et al., 2001), applying the tests of Pettitt (1979) and Buishand (1982). Finally, both pluviometric and pluviographic data were analyzed for the detection of outliers (Kite, 1988; González Rouco et al., 2001; Chebana et al., 2012), according to the procedure given by Chow et al. (1994).

For each location, moments of order $q$ between 1 and 7 were deduced for different $d$ values for test the validity of the scale invariance hypothesis and the deduction of the value of the scaling factor $\ddot{e}$ according to Equation (4).

From Equation (3) Menabde et al. (1999) proposes a model based on equations (5), (6) (7) and (8) to solve Equation (1), allowing to obtain the values of $i$ to a $d$ duration, knowing the value of $i$ at a duration $D$, which in the present work is 24 hours, where $\mu$ and $\sigma$ are constants.

$$
\begin{aligned}
& a(T)=\mu+\sigma \ln [-\ln (1-(1 / T))] \\
& (d)=d^{\lambda} \\
& \mu=\mu_{D} D^{\lambda} \\
& \sigma=\sigma_{D} D^{\lambda}
\end{aligned}
$$


As proposed by Menabde et al.(1999), maximum annual values of daily intensity ( $d=1440$ minutes) of each location were adjusted to the accumulated distribution function of Gumbel (Chow et al., 1994), presented in equation (9). Equations (10) and (11) define $\mu D$ and $\sigma D$, where $m$ and $s$ are the sample mean and variance, respectively. For the ordering of values and the construction of the Blom plotting position was used (Chow et al., 1994).

$$
\begin{aligned}
& F(x)=\exp \left[-\exp \left(-\frac{x-\mu}{\sigma}\right)\right] \\
& \sigma_{D}=\sqrt{6} s / \pi \\
& \mu_{D}=m-0.5772 \sigma_{D}
\end{aligned}
$$

The relationship between daily precipitation and sub-hourly intensity was established by setting the equations (5), (6), (7) and (8). The estimation was obtained by simple scaling the precipitation values for $d$ between 5 and 1440 minutes for the return times of 2 to 100 years, from the total daily precipitation.

The results were validated in two independent ways: a) They were compared to the IDF curves constructed in this work for each location with the available rainfall intensity data, applying the formulation proposed by Koutsoyiannis et al. (1998), adjusting the cumulative probability distribution function of EVIII (Chow et al., 1994); b) They were compared in different cases from the antecedent IDF curves available in the bibliography (indicated in the figures as "K-formula"), for the same locations analyzed (Table 1). All locations except Castelar and Bella Vista were validated due the lack of available information regarding IDF curves previously performed by other authors.

Table 1. Cases with available IDF curves and rainfall intensity data used for the validation of the scaling. $S / d$ : no information.

\begin{tabular}{|c|c|c|c|c|}
\hline Case & Location & $\begin{array}{c}\text { Global period } \\
\text { analyzed }\end{array}$ & $\begin{array}{c}\text { T interval } \\
\text { analyzed (years) }\end{array}$ & Author \\
\hline 1 & Balcarce & $1972-1979$ & $2-100$ & Vidal y Cousillas (1982) \\
2 & Balcarce & $1991-2006$ & $2-100$ & Puricelli (2014) \\
3 & Marcos Juárez & $1972-1986$ & $2-10$ & Scotta et al. (1989) \\
4 & Santa Rosa & $1948-1974$ & $2-10$ & Mauriño (2004) \\
\hline
\end{tabular}

The uncertainty associated with the estimates was assessed by a 95\% confidence interval estimated by non-parametric bootstrap (Van de Vyver and Demarée, 2010). According to these authors, for each location, a random sampling with replacement was carried out with the replacement of the observed data. This process was performed 50000 times for each location. For each of these samples, the estimation of $\lambda, \sigma$ and $\mu$ was performed as previously indicated. With these values, the values of precipitation intensity 
of between 5 and 1440 minutes and for $T$ between 2 and 100 years were estimated. Finally, the precipitation intensity quantiles in the different combinations of $d$ and $T$ were sorted in ascending order and the $95 \%$ confidence interval was estimated (Van de Vyver and Demarée, 2010). The relative uncertainty was expressed as the ratio between the difference of the values of the confidence interval and the median of the intensities (Van de Vyver and Demarée, 2010), in order to establish the reliability of the estimates.

In agreement with Ghanmi et al. (2016), a first attemp of regionalization was carried out through the interpolation of the $\lambda$ parameter (equations 6,7 and 8) and $\mu_{D}$ and $\sigma_{D}$ parameters (equations 10 and 11) on Pampean region, using the Inverse Square Distance method (Isaaks and Srivastava, 1999). These results were validated in 23 cases, corresponding to IDF curves taken from the literature (indicated in the figures as "conventional") and corresponding to 17 locations, different from those used in the previous validation stage (Table 2).

Table 2. Cases with information used for the validation of scaling using regionalized parameters. s/d: no information.

\begin{tabular}{|c|c|c|c|c|}
\hline Case & Location & $\begin{array}{l}\text { Global period } \\
\text { analyzed }\end{array}$ & $\begin{array}{c}T \text { interval } \\
\text { analyzed } \\
\text { (years) }\end{array}$ & Author \\
\hline 5 & Azul & 1995- 2004 & $2-10$ & Varela et al. (2003) \\
\hline 6 & Azul & $1966-2008$ & 5- 50 & Collazos y Cazenave (2015) \\
\hline 7 & Bahía Blanca & $1951-1988$ & $2-50$ & Sequeira (2007) \\
\hline 8 & Gualeguaychú & $1951-1971$ & $2-10$ & Scotta et al. (1989) \\
\hline 9 & Junín & $1943-1973$ & $2-10$ & Scotta et al. (1989) \\
\hline 10 & Mar del Plata & $\mathrm{s} / \mathrm{d}$ & 2 & Mauriño (2004) \\
\hline 11 & Oliveros & 1964- 1986 & $2-10$ & Scotta et al. (1989) \\
\hline 12 & Pehuajó & $\mathrm{s} / \mathrm{d}$ & 2 & Mauriño (2004) \\
\hline 13 & Pergamino & $1953-1983$ & $2-10$ & Scotta et al. (1989) \\
\hline 14 & Pergamino & $1972-1984$ & $2-10$ & Mauriño (2004) \\
\hline 15 & Punta Alta & $\mathrm{s} / \mathrm{d}$ & 2 & Mauriño (2004) \\
\hline 16 & Rosario & $1942-1984$ & $2-100$ & Basile et al. (2011) \\
\hline 17 & San Pedro & $1969-1985$ & $2-10$ & Scotta et al. (1989) \\
\hline 18 & Tandil & $1972-1980$ & $2-5$ & Mauriño (2004) \\
\hline 19 & Tres Arroyos & $\mathrm{s} / \mathrm{d}$ & $2-10$ & Mauriño (2004) \\
\hline 20 & Villa Ortúzar & $1937-1957$ & $2-100$ & Mauriño (2004) \\
\hline 21 & Villa Ortúzar & $\mathrm{s} / \mathrm{d}$ & $2-50$ & Devoto (2011) \\
\hline 22 & Concordia & $1961-2004$ & $2-50$ & Zamanillo et al.(2008) \\
\hline 23 & Concepción del Uruguay & $1954-1986$ & $2-10$ & Scotta et al. (1989) \\
\hline 24 & Concepción del Uruguay & $1963-2005$ & $2-50$ & Zamanillo et al. (2008) \\
\hline 25 & Paraná & $1965-1986$ & $2-10$ & Scotta et al. (1989) \\
\hline 26 & Paraná & $\mathrm{s} / \mathrm{d}$ & $2-100$ & Mauriño (2004) \\
\hline 27 & Paraná & $1980-2005$ & $2-50$ & Zamanillo et al. (2008) \\
\hline
\end{tabular}


The IDF curves in cases 5 to 27 were elaborated following any of the conventional empirical procedure described by Garcia-Bartual and Scheider (2001).

Following Maillot et al. (2007), the validation of the regionalization, estimated quantiles by simple scaling were compared to the available IDF curves for the same values of $T$ and $d$ respectively, and the goodness to fit indicator was the correlation coefficient $r$ (Montgomery and Runger, 1996) between the ordered available IDF values ay the estimated by simple scaling.

For the information processing, the R package (Ihaka and Gentleman, 1996) and the G numeric spreadsheet were used (Nash, 2010).

\section{Results and discussion}

\subsection{Scale invariance and simple scaling analysis}

In all localities, the analysis of the statistical moments of the precipitation intensity confirmed the validity of the invariance hypothesis. The values of $R^{2}$ of the linear adjustment by simple regression (Montgomery and Runger, 1996) exceeded 99\% in all cases (Fig. 3). Figure 3 describes a group locations distinguishing themselves from another: on the one hand, Santa Rosa, Balcarce, Marcos Juárez and Castelar, on the other Bella Vista. The result indicates a strong validity of the simple scaling property of the extreme rainfall in time series. Consequently, in the Pampean Region it is possible to represent the precipitation intensity at different values of duration and return time by simple scaling.

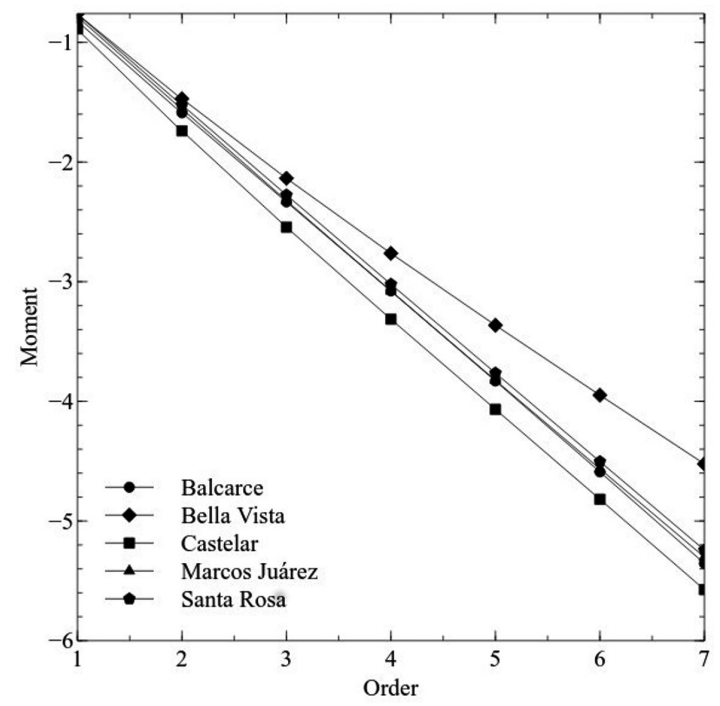

Figure 3. Relation of moments for different orders.

Table 3 shows the value of the scale coefficient $\lambda$ for each location analyzed. The values are generally uniform, unlike other cases presented in the world (Nhat et al., 2008; Bara et al., 
2010), where between the minimum and maximum $\lambda$ values there is only a $20 \%$ difference. Particularly, the value for Bella Vista is similar with the presented by Naghettini (2012) for a location in southern Brazil, confirming the difference with the other localities.

Table 3. Scaling parameter $\lambda$ used in the rainfall modeling.

\begin{tabular}{|c|c|}
\hline Locations & $\lambda$ \\
\hline Balcarce & 0.754 \\
Bella vista & 0.624 \\
Castelar & 0.776 \\
Marcos Juarez & 0.753 \\
Santa Rosa & 0.746 \\
\hline
\end{tabular}

From the values in Table 3 , the IDF curves were estimated by simple scaling for the analyzed locations using equations (5), (6), (7) and (8). The results are shown in Table 4.

Table 4. Rainfall intensity estimates in calibration cases.

\begin{tabular}{|c|c|c|c|c|c|c|}
\hline$d$ & $T$ & Santa Rosa & Balcarce & Castelar & Marcos Juárez & Bella Vista \\
\hline \multirow{4}{*}{5} & 2 & 147 & 228 & 267 & 195 & 173 \\
\hline & 10 & 310 & 334 & 361 & 315 & 267 \\
\hline & 50 & 452 & 427 & 443 & 421 & 348 \\
\hline & 100 & 512 & 467 & 477 & 465 & 383 \\
\hline \multirow{4}{*}{30} & 2 & 39 & 59 & 67 & 51 & 57 \\
\hline & 10 & 81 & 87 & 90 & 82 & 87 \\
\hline & 50 & 119 & 111 & 110 & 109 & 114 \\
\hline & 100 & 135 & 121 & 119 & 121 & 125 \\
\hline \multirow{4}{*}{60} & 2 & 23 & 35 & 39 & 30 & 37 \\
\hline & 10 & 48 & 51 & 52 & 49 & 57 \\
\hline & 50 & 71 & 66 & 64 & 65 & 74 \\
\hline & 100 & 80 & 72 & 69 & 72 & 81 \\
\hline \multirow{4}{*}{720} & 2 & 4 & 5 & 6 & 5 & 8 \\
\hline & 10 & 8 & 8 & 8 & 7 & 12 \\
\hline & 50 & 11 & 10 & 9 & 10 & 16 \\
\hline & 100 & 13 & 11 & 10 & 11 & 17 \\
\hline \multirow{4}{*}{1440} & 2 & 2 & 3 & 3 & 3 & 5 \\
\hline & 10 & 5 & 5 & 4 & 4 & 8 \\
\hline & 50 & 7 & 6 & 5 & 6 & 10 \\
\hline & 100 & 8 & 7 & 6 & 7 & 11 \\
\hline
\end{tabular}

The estimated values of the rainfall intensities decrease from the smallest periodicity and the shortest duration to higher $T$ and longer $d$. Such behavior is typical of such data, which indicates that the simple scaling method can be suitable for assessing IDF curves in these cases. 
An important part of the sensitivity of the estimated IDF curves is a function of the values of the scaling coefficient $\lambda$ (Bara et al., 2010). Comparing the extremes of rainfall intensity estimated for $d=5$ minutes and $T=100$ years at the locations in Bella Vista and Castelar, while the difference in scale coefficient is $19 \%$, precipitation intensity values varies by $14 \%$. However, the greatest differences in intensity were observed between Santa Rosa and Bella Vista, where the difference in scale parameter is $16 \%$ and the difference in intensity of $25 \%$. These results indicate that the $\mu_{D}$ and $\sigma_{D}$ parameters contribute to the difference of intensity values estimated by this model, and that it is not possible to use a single set of parameters for the total of the Pampean region.

\subsection{Validation of simple scaling}

Figures 4 and 5 indicate the results of the validation of the simple scaling estimates for the analyzed locations. Figure 4 shows a high degree of coincidence between the values estimated by the model proposed by Menabde et al. (1999) with those estimated according to the formulation proposed by Koutsoyiannis et al. (1998), with $r$ greater than 0.99 in all cases. In general, fitting is better in the high values of intensity, with respect to the lower ones. Simple scaling model differs slightly in the values of lower precipitation intensity, compared to those obtained by the formulation proposed by Koutsoyiannis et al. (1998). The heterogeneity in the origin and quantity of the data used did not influence the quality of the fit.
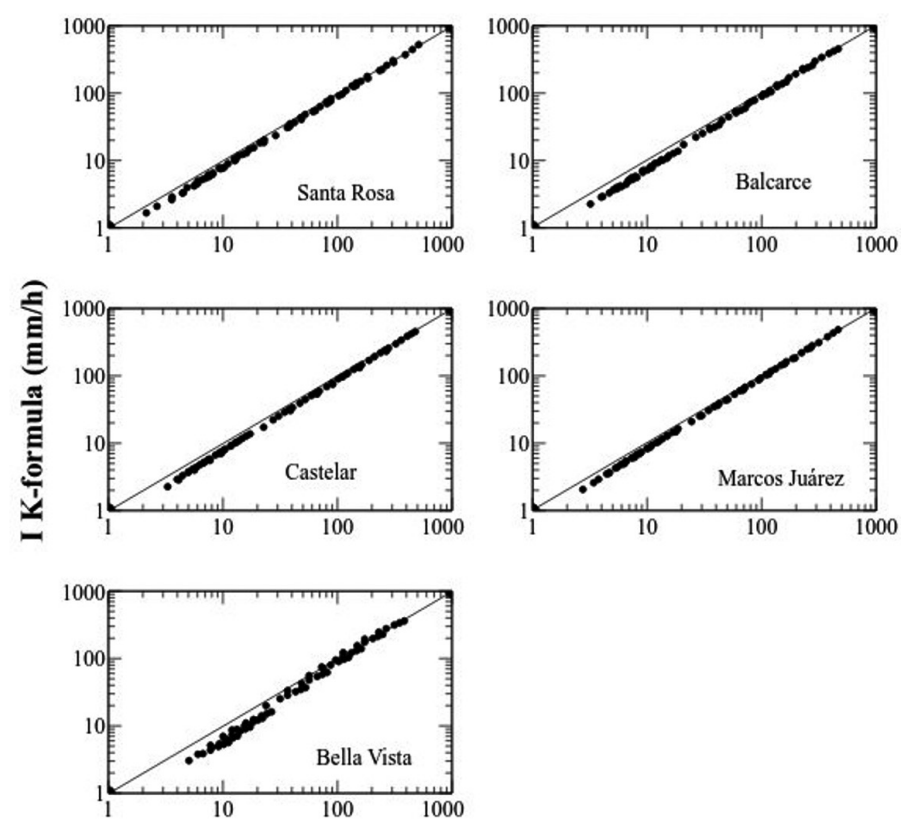

\section{Simple scaling $(\mathbf{m m} / \mathbf{h})$}

Figure 4.Validation between simple scaling estimates with respect to the applying the model proposed by Koutsoyiannis et al.(1998). 
Figure 5 indicate the validation of the values estimated by simple scaling with respect to the IDF curves available in the bibliography for all the analyzed locations except Castelar and Bella Vista (Table 3). The goodness to fit between the simple scaling model and the available IDF curves is also high, regardless of the source of the information and the time of return associated with the estimated quantile. The $r$ values obtained are greater than 0.98 , indicating a good fit overall. The greatest differences are observed in the Balcarce (Case 1) with the overestimation of the intensities corresponding to values of d less than 30 minutes, for different $T$ values.

It is noteworthy that both the verification of the scale invariance hypothesis and the close relationship between the IDF curves estimated by both pathways did not show differences attributable to their spatial location, $d$ value, or by the amount of data available analyzed in each location.

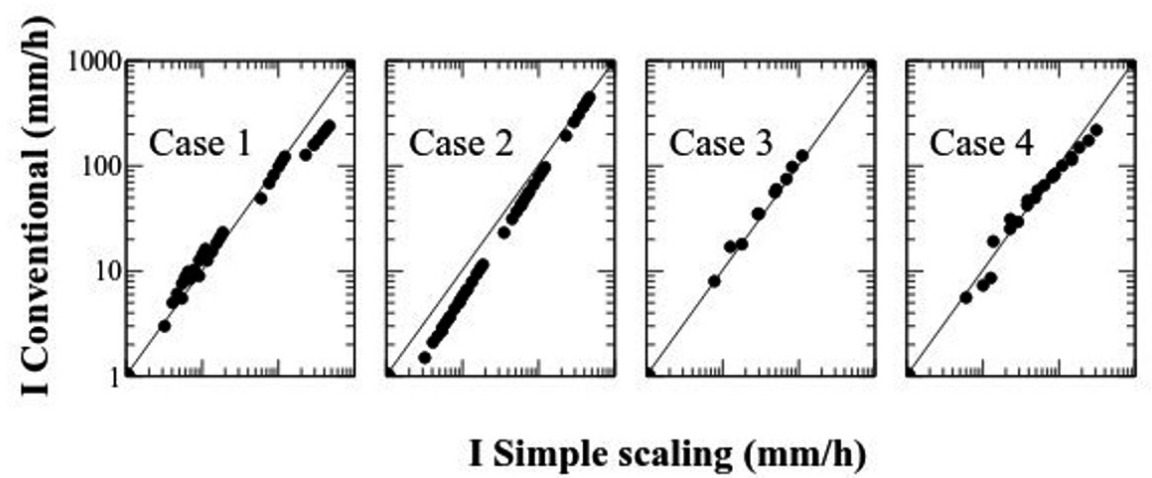

Figure 5. Validation of simple scale estimates with IDF curves in the cases studied.

\subsection{Uncertainty analysis}

First, it could be concluded that the IDF curves would be relatively short and, consequently, part of the values come from extrapolations form a mathematical model which is a simplification of a highly complex and variable natural process. To address this problem, confidence intervals are commonly used to provide an idea of the accuracy of an estimate. In this work, we obtained confidence intervals for the estimated rainfall intensity for different values of $d$ and $T$ through the bootstrap technique. Table 5 summarizes $95 \%$ confidence intervals for $T$ form 2 to 100 years and $d$ form 5 minutes to 24 hours. It is clearly observed that, because of the length of the data series used, confidence intervals extend significantly when rainfall intensity increases, in those cases where $d$ are small and $T$ large. However, the confidence interval is insufficient to draw conclusions about the reliability of the estimates (Van de Vyver and Demarée, 2010). 
Figure 6 shows the distribution of relative uncertainty for the five calibration cases analyzed, according to different $d$ values. This figure shows a nonlinear relationship between relative uncertainty and duration. The highest values of relative uncertainty are associated with duration less or equal to 30 minutes, and minimal for durations more than 720 minutes.

Table 5. Confidence Intervals (95\%) for rainfall intensity estimates $(\mathrm{mm} / \mathrm{h})$ in calibration cases.

\begin{tabular}{|c|c|c|c|c|c|c|}
\hline $\boldsymbol{d}$ & $\boldsymbol{T}$ & Santa Rosa & Balcarce & Castelar & Marcos Juárez & Bella Vista \\
\hline \multirow{5}{*}{5} & $\mathbf{2}$ & $118-242$ & $165-296$ & $168-706$ & $104-431$ & $142-320$ \\
& $\mathbf{1 0}$ & $211-458$ & $244-422$ & $227-966$ & $169-687$ & $204-504$ \\
& $\mathbf{5 0}$ & $290-652$ & $308-537$ & $278-1197$ & $225-915$ & $255-667$ \\
& $\mathbf{1 0 0}$ & $324-735$ & $335-587$ & $300-1292$ & $248-1011$ & $277-736$ \\
\hline \multirow{3}{*}{$\mathbf{3 0}$} & $\mathbf{2}$ & $31-61$ & $46-71$ & $48-129$ & $32-88$ & $48-87$ \\
& $\mathbf{1 0}$ & $56-113$ & $68-101$ & $65-176$ & $52-140$ & $69-137$ \\
& $\mathbf{5 0}$ & $77-161$ & $86-130$ & $80-218$ & $69-187$ & $86-182$ \\
& $\mathbf{1 0 0}$ & $87-181$ & $93-142$ & $86-236$ & $76-207$ & $94-201$ \\
\hline \multirow{5}{*}{$\mathbf{6 0}$} & $\mathbf{2}$ & $18-35$ & $28-41$ & $30-67$ & $20-47$ & $31-52$ \\
& $\mathbf{1 0}$ & $33-66$ & $41-59$ & $40-91$ & $33-76$ & $45-83$ \\
& $\mathbf{5 0}$ & $46-94$ & $52-75$ & $49-113$ & $44-101$ & $57-110$ \\
& $\mathbf{1 0 0}$ & $52-106$ & $56-82$ & $53-122$ & $48-112$ & $61-122$ \\
\hline \multirow{3}{*}{$\mathbf{7 2 0}$} & $\mathbf{2}$ & $2-5$ & $4-6$ & $5-6$ & $3-5$ & $6-9$ \\
& $\mathbf{1 0}$ & $5-9$ & $6-8$ & $7-8$ & $6-8$ & $9-14$ \\
& $\mathbf{5 0}$ & $7-13$ & $8-11$ & $8-10$ & $8-11$ & $12-18$ \\
& $\mathbf{1 0 0}$ & $8-15$ & $9-12$ & $9-11$ & $8-13$ & $13-20$ \\
\hline & $\mathbf{2}$ & $1-3$ & $2-3$ & $2-3$ & $2-3$ & $4-5$ \\
& $\mathbf{1 0}$ & $3-5$ & $4-5$ & $4-4$ & $3-5$ & $6-8$ \\
$\mathbf{1 4 4 0}$ & $\mathbf{5 0}$ & $4-8$ & $5-6$ & $5-5$ & $4-6$ & $7-11$ \\
& $\mathbf{1 0 0}$ & $4-9$ & $5-7$ & $5-6$ & $5-7$ & $8-13$ \\
\hline
\end{tabular}

In hydrological design, flood protection works, etc., hydrological models are adopted to estimate the design flows associated with given probability. These models require a design rain, and this usually depends on an IDF curve (Chow et al., 1994). The size and importance of the works are related to a return period (Chow et al., 1994), thus depend on the available hydrological information. In our case, the shortage of data generates uncertainty that could not be considered without confidence intervals. Figure 6 summarizes this situation, by three different levels of uncertainty $(d<30$ minutes, 30 minutes $<d<720$ minutes, $d>720$ minutes, respectively) for modeling and design works. 


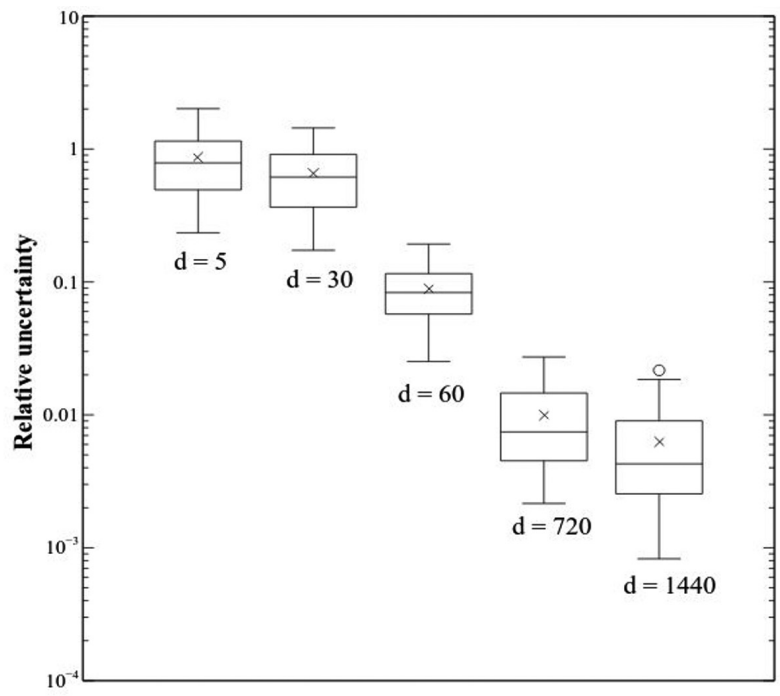

Figure 6. Distribution of relative uncertainty values for different values of $d$.

\subsection{Regionalization}

The estimated spatial distribution of $\mu_{D}, \sigma_{D}$ and $\lambda$ for the Pampean region is shown in Figure 7. They suggest the existence of climatic differences, in agreement with Menabde et al. (1999). The values of $\mu_{D}$ and $\sigma_{D}$ match with some of the regional climatic characteristics previously observed by other authors. In general an increase of the values of $\mu_{D}$ from the SW to the NE is observed, which agrees with the distribution of the extreme values of precipitation intensity exposed by Robledo and Penalba (2008). On the other hand, $\sigma_{D}$ is directly related to the dispersion of the distribution of values (Equation 10) and its highest values are observed both towards the NE and SW extremes of the Pampean region (Bella Vista, and Santa Rosa, respectively), similar to those presented by Díaz and Masiero (1984), whereas $\lambda$ shows the opposite trend and $\sigma_{D}$ shows a NW - SE bearing valley at the center of the region.
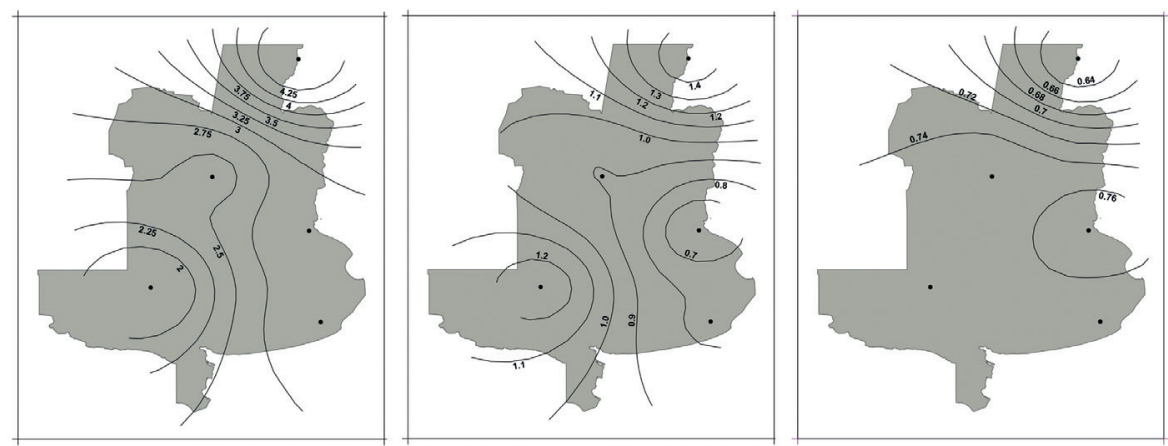

Figure 7. Spatial distribution of $\mu D($ left $), \sigma D$ (center) and $\lambda$ (right.) 
Figure 8 shows the trend of precipitation intensity for different values of $d$ and $T$, estimated from the data available at the calibration of the model. It can be verified a general trend from $\mathrm{W}$ to $\mathrm{E}$ and $\mathrm{NE}$, indicating coincidences with the distribution of extreme values expressed by Robledo and Penalba (2008) and Díaz and Masiero (1984). However, this trend is not uniform, in addition to the difference between the intensity values estimated at the aforementioned geographic extremes, in the center of the region there is a clear difference of values. Therefore, it is important to note that a low zone with SE-NE bearing, which interferes with the continuous growth of the trend, is especially evident for high $\mathrm{T}$ values and $d$ equal or less to 60 minutes.
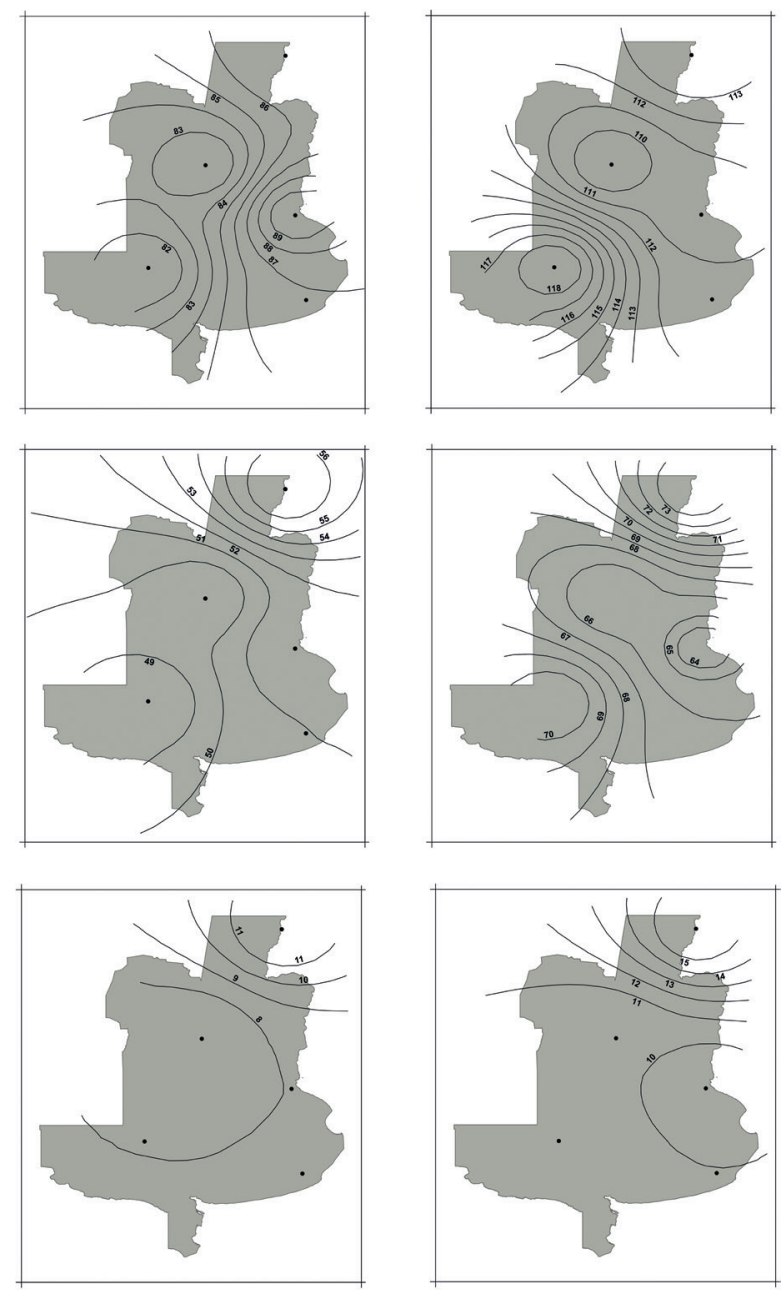

Figure 8. Spatial distribution of rainfall intensity for different combination of $d$ and T. Upper left: $d=30$ minutes and $T=10$ years. Upper right: $d=30$ minutes, $T=50$ years. Center left: $d=60$ minutes, $T=10$ years, Center rihgt: $d=60$ minutes, $T=50$ years. Lower left: $d=720$ minutes, $T=10$ years. Lower right: $d=720$ minutes, $T=50$ year.s 
Despite the small number of localities available, this regionalization allows the reconstruction of intentional nonlinear precipitation. Considering that the territory is, in general, a broad plain with small relative relief (Fig. 1), the regionalization can be considered as plausible and the variations in the spatial distribution of the rainfall intensities shows the sensibility of the model.

\subsection{Validation of regionalization}

The results validation obtained from the estimation of the antecedent IDF curves for the 17 locations analyzed are shown in figures 9 and 10. As in the previous case, the results were highly satisfactory. The values of $r$ obtained are higher than $90 \%$, except for the estimation indicated by Sequeira (2007) for Bahía Blanca $(r=89 \%)$.

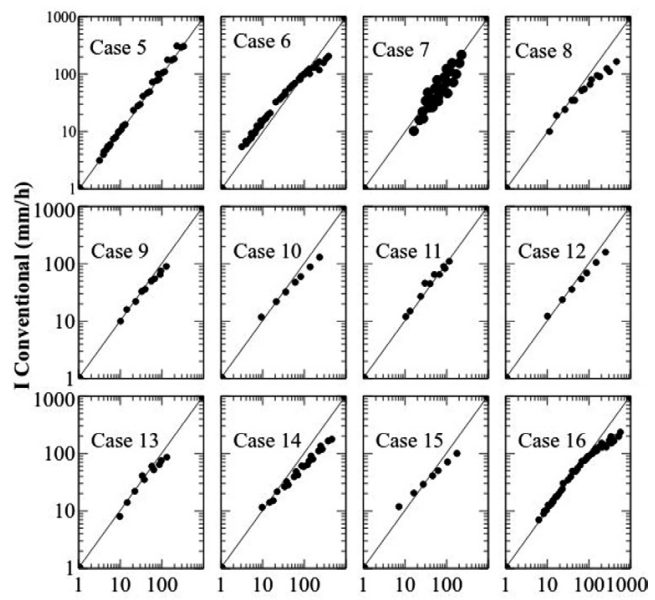

Figure 9. Validation of simple scale estimates with existing IDF curves in the analyzed cases.

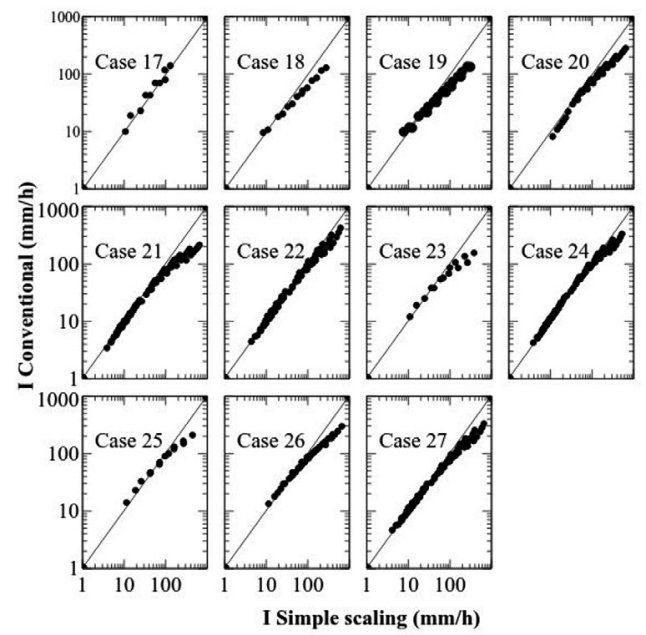

Figure 10. Validation of simple scale estimates with existing IDF curves in the locations analyzed (Cont.). 
In most cases analyzed (20 of 23 ) the estimates made by simple scaling are greater than the bibliographical references for high values of precipitation intensity. These differences are associated with values of $d$ less than 30 minutes, independently of the $T$ values considered. It is not possible to establish a geographical pattern or a relationship with the time interval associated with the IDF curves analyzed, nor with the historical length they represent. This problem was already reported by other authors. García-Bartual and Schneider (2001) showed that short duration rainfall intensities are affected by a large uncertainty when durations under 10 or 5 minutes are considered, especially when they are produced during extreme convective rainfall events. Consistent with the dynamics of the maximum rainfall intensities, produced by mechanisms at different time scales, IDF relationships are more suitable when data for larger durations ( $d$ less than 60 minutes) are considered (García-Bartual and Scheider, 2001; Langousis and Veneziano, 2007). Another source of error is the degree of the complexity of the empirical equations commonly used in the construction of IDF curves affects the rainfall intensity estimations (García-Bartual and Schneider, 2001) while model-based IDF curves are smoother than the empirical ones (Langousis and Veneziano, 2007).

In the Pampean region, the simple scaling model of the rain presented in this work has proved its validity reproducing the observational data, maintaining a reasonable degree of uncertainty, its practicality and reproducibility, in different situations using freely accessible tools.

The availability of rainfall information requires extensive networks of data collection, with continuity over time (Bell, 1969). This observation is valid for Argentina and other countries of the region (Mauriño, 2004), but unfortunately this requirement is difficult to meet under current socio-economic conditions. Due to the fact that the usual hydrological hypothesis to estimate the maximum runoff rate is based on considering that the duration of the storm that generates it should be at least equal to the basin concentration time (Chow et al., 1994), the lack of rainfall information implies a major limitation for the hydrological design. In this work it has been demonstrated that simple scaling from daily precipitation data may be a valid alternative to solve this limitation in the Pampas region. The results contribute to fill the wide information gap by providing reference values of $\lambda, \mu_{D}$ and $\sigma_{D}$ of reference for the construction or updating of IDF curves in those locations where such information is necessary.

There is a close coincidence between the two estimates. This makes it possible to affirm that simple scaling coincides acceptably with the intensity, duration and frequency relationships previously estimated by other authors in the seventeen different locations distributed in the Pampean region.

From the point of view of the complexity of the phenomenon being analyzed, the results allow us to affirm that, at least in the Pampean region, the IDF curves constructed by simple scaling contribute a parsimonious and operational synthesis regarding the complex mechanisms that dominate the processes of precipitation on a particular scale (Burlando and Rosso, 1996). 


\section{Conclusions}

This work presents the first results obtained in the experimentation and investigation of mathematical relation for the change of temporal scale in values of rainfall intensity, for 5 cases, and validated in another 23 more in the Pampean region. Four main conclusions can be highlighted:

1) First, it was verified the scale invariance hypothesis and the possibility of applying a simple scale model based on pluviometric and pluviographic information, recorded in climatically and ecologically different locations.

2) The simple scale model sowed a very good fit in comparison with conventional model. Results provide new evidence on scale relationships in hydrological variables.

3) The inclusion of an uncertainty analysis, allowed to define the confidence limits for the rainfall intensity estimates, showing good perspectives in the development of hydrological applications in the region.

4) The present work provides criteria and reference values for the construction and update of IDF curves un the Pampean region, where they are highly required, leading to future advances in hydrology in areas with little or no rainfall information.

\section{Acknowledgements}

The author wish to thanks to Guillermo Casagrande, Álvaro Andreucci and Graciela Cazenave for collaborate with information, and Marcelo Huarte for help and review. This work is part of the research activities planned in the project PNSUELO 1134022: "Soil degradation, conservation and management. Water and wind erosion", that are developed in the Balcarce Experimental Agricultural Station, from National Institute of Agricultural Technology, Argentina.

\section{References}

Aliaga, V.S., Ferrelli, F., Alberdi-Algañaraz, E.D., Bohn, V.Y., Piccolo, M.C. 2016. Distribution and variability of precipitation in the Pampas, Argentina. Cuadernos de Investigación Geográfica 42 (1), 261-280. http://doi.org/10.18172/cig.2867.

Bara, M., Kohonová, S., Szolgay, J., Gaál, L., Hlavčová, K. 2010. Assessing of IDF curves for hydrological design by simple scaling of 1-day precipitation totals. Slovak Journal of Civil Engineering 3, 1-6. http://www.svf.stuba.sk/docs/sjce/2010/2010_3/file2.pdf.

Basile, P.A., Riccardi, G., Stenta, H. 2011. Derivación y parametrización de curvas IDR para Rosario, Casilda y Zavalla (Santa Fé, Argentina). In: G. Riccardi, H. Stenta, C.M. Scuderi, P.A. Basile, E. Zimmermann (Eds.), III Taller sobre Regionalización de Precipitaciones Máximas. Universidad Nacional de Rosario, pp. 217-226.

Blanchet, J., Ceresetti, D., Molinié, G., Creutin, J.D. 2016. A regional GEV scale-invariant framework for intensity-duration-frequency analysis. Journal of Hydrology 540, 82-95. https://doi.org/10.1016/j.jhydrol.2016.06.007. 
Blöschl, G., Sivapalan, M. 1995. Scale issues in hydrological modeling: A review. Hydrological Processes 9 (3-4), 251-290. https://doi.org/10.1002/hyp.3360090305.

Blöschl, G. 2001. Scaing in hydrology. Hydrological Processes 15, 709-711. https://doi. org/10.1002/hyp.432.

Bocchiola, D., De Michele, C., Rosso, R. 2003. Review of recent advances in index flood estimation. Hydrology and Earth System Sciences 7 (3), 283-296. https://hal.archivesouvertes.fr/hal-00304779/document.

Bougadis, J., Adamowski, L. 2006. Scaling model of rainfall intensity - duration - frequency relationship. Hydrological Processes 20 (17), 3747-3757. https://doi.org/10.1002/hyp.6386.

Buckart, R., Bárbaro, N.O., Sánchez, R.O., Gómez, D.A. 1999. Eco-regiones de la Argentina. Administración de Parques Nacionales, Buenos Aires, 42 pp.

Buishand,T.A. 1982. Some methods for testing the homogeneity of rainfall records. Journal of Hydrology 58,11-27.http://www.homogenisation.org/files/private/WG1/Bibliography/Comparisons_and_ Reviews/buishand.pdf.

Burgos, V., López, P., Maza, J., Salcedo, A. P. 2015. Delimitación de áreas de riesgo hídrico por crecidas de los ríos El Tala y Paclín, Catamarca. Actas del XXV Congreso Nacional de Agua, Argentina, Paraná, pp. 344-356.

Burlando, P., Rosso, R. 1996. Scaling and multiscaling models of depth-duration-frequency curves for storm precipitation. Journal of Hydrology 187 (1-2), 45-64. https://doi.org/10.1016/ S0022-1694(96)03086-7.

Casas, R. 2015. La erosión del suelo en Argentina. In: R. Casas, G.F. Albarracín (Eds.), El deterioro del suelo y el ambiente en la Argentina. Tomo II. FECIC. Buenos Aires, pp. 433-452.

Chebana, F., Dabo-Niang, S., Ouarda, T.B.M.J. 2012. Exploratory functional flood frequency analysis and outlier detection. Water Resources Research 48 (4), W04514. http://doi. org/10.1029/2011WR011040.

Chow, V.T., Maidment, D.R., Mays, L.W. 1994. Hidrología Aplicada. Mc Graw Hill, Bogotá, 584 pp.

Collazos, G., Cazenave, G. 2015. Curvas IDF para el centro de la Pcia. De Buenos Aires. Actas del XXV Congreso Nacional del Agua. Paraná, pp. 480-486. https://pilotosaladesituacion.files. wordpress.com/2015/01/conagua2015_resumenes-p287-y-303.pdf.

Davison, J., Wong, M. C. 2005. Guidelines on integrating severe weather warnings into disaster risk management. World Meteorological Organization, WMO/TD 1292, Geneva. 26 pp. https://www.wmo.int/pages/prog/amp/pwsp/pdf/TD-1292.pdf.

Devoto, G.A. 2011. Hidrología de las crecidas en el AMBA. In: A. Kreimer, D. Kullock, F.B. Baldés (Eds.), Inundaciones en el Área Metropolitana de Buenos Aires. The World Bank. Disaster Risk Management Working Paper Series 3, pp. 91-107. http://siteresources.worldbank.org/ INTDISMGMT/Resources/buenosaires.pdf.

Di Leo, C.M., Aragón, A., Marlats, R., Bruno, J.E. 1999. Erosividad de las precipitaciones en Tandil, Provincia de Buenos Aires. Ciencia del Suelo 17 (2), 58-61. https://www.suelos.org. ar/publicaciones/vol_17n2/di_leo_58-61.pdf.

Durrans, S.R., Kirby, J.T. 2004. Regionalization of extreme precipitation estimates for the Alabama rainfall atlas. Journal of Hydrology 295 (1-4), 101-107. https://doi.org/10.1016/j. jhydrol.2004.02.021.

Easterling, D.R., Evans, J.L., Groisman, Y., Karl, T.R., Kunkel, K.E., Ambenje, P. 2000. Observed variability trends in extreme climate events: a brief review. Bulletin of the American Meteorology Society 81 (3), 417-425. https://doi.org/10.1175/1520-0477(2000)081<0417:OV ATIE $>2.3 . \mathrm{CO} ; 2$. 
Gabriels, D. 2006. Assessing the Modified Fournier Index and the Precipitation Concentration Index for some European countries. In: J. Poesen (Ed.), Soil Erosion in Europe. John Wiley and Sons, Chichester, pp. 675-684. https://doi.org/10.1002/0470859202.

García-Bartual, R., Schneider, N. 2001. Estimating maximum expected short-duration rainfall intensities from extreme convective storms. Physics and Chemistry of the Earth, Part B: Hydrology, Oceans and Atmosphere 26 (9), 675-681. https://doi.org/10.1016/S14641909(01)00068-5.

Gebremichael, M., Over, T.M., Krajewsky, W.F. 2006. Comparison of the scaling characteristics of rainfall derived from space-based and ground-based radar observations. Journal of Meteorology 7, 1277-1249. https://doi.org/10.1175/JHM549.1.

Gentine, P., Troy, T.J., Lintner, B.R., Findell, K.L. 2012. Scaling in surface hydrology: Progress and challenges. Journal of Contemporary Water Research \& Education 147 (1), 28-40. http:// doi.org/10.1111/j.1936-704X.2012.03105.x.

Ghanmi,H., Bargaoui,Z., Mallet, C. 2016.Estimation of intensity-duration-frequency relationships according to the property of scale invariance and regionalization analysis in a Mediterranean coastal area. Journal of Hydrology 541, 38-49. https://doi.org/10.1016/j.jhydrol.2016.07.002.

González-Rouco, F., Jiménez, J.L., Quesada, V., Valero, F. 2001. Quality control and homogeneity of precipitation data in the southwest of Europe. Journal of Climate 14, 964-978. https://doi. org/10.1175/1520-0442(2001)014<0964:QCAHOP>2.0.CO;2.

Gupta, V.K., Waymire, E. 1987. On Taylor's hypothesis and dissipation in rainfall. Journal of Geophysical Research 92 (D8), 9657-9660. http://doi.org/10.1029/JD092iD08p09657.

Gupta, V.K., Waymire, E. 1990. Multiscaling properties of spatial rainfall and river flow distributions. Journal of Geophysical Research 95 (D3), 1999-2009. https://doi.org/10.1029/ JD095iD03p01999.

Hailegeorgis, T., Thorolfsson, S.T., Alfredsen, K. 2013. Regional frequency analysis of extreme precipitation with consideration of uncertainties to update IDF curves for the city of Trondheim. Journal of Hydrology 498, 305-318. https://doi.org/10.1016/j.jhydrol.2013.06.019.

Ihaka, R., Gentleman, R. 1996. R: A language for data analysis and graphics. Journal of Computation and Graphical Statistics 5 (3), 299-314. http://doi.org/10.2307/1390807.

Intergovernamental Panel of Climate Change. 2012. Managing the risks of extremes events and disasters to advance climate change adaptation. Cambridge University press, $582 \mathrm{pp}$. https:// www.ipcc.ch/pdf/special-reports/srex/SREX_Full_Report.pdf.

Isaaks, E.H., Srivastava, R.M. 1999. Applied Geostatistics. Oxford University Press, Oxford, 561 pp. ftp://shock.geomatics.ncku.edu.tw/array1/for_test/IsaaksBook.pdf.

Jiang, P., Tung, Y.K. 2013. Establishing rainfall depth-duration-frequency relationships at daily rain gauge stations in Hong Kong. Journal of Hydrology 504, 80-93 . https://doi.org/10.1016/j. jhydrol.2013.09.037.

Karl, T.R., Easterling, D.R. 1999. Climate extremes: selected review and future research directions. Climatic Change 42 (1), 309-325. https://doi.org/10.1007/978-94-015-9265-9_17.

Kite, G. 1988. Frequency and risk analyses in hydrology. Water Resources Publications, Littleton, Colorado. 257 pp.

Klemeš, V. 1983. Conceptualization and scale in hydrology. Journal of Hydrology 65 (1-3), 1-23. https://doi.org/10.1016/0022-1694(83)90208-1.

Koutsoyiannis, D., Kozonis, D., Manetas, A. 1998. A mathematical framework for studying rainfall intensity duration frequency relationships. Journal of Hydrology 206, 118-135. https://doi. org/10.1016/S0022-1694(98)00097-3.

Kundzewicz, Z., Robson, A.J. 2004. Change detection in hydrological records-a review of the methodology. Hydrological Sciences, 49 (1), 7-19. http://doi.org/10.1623/hysj.49.1.7.53993. 
Kunkel, K.E., Andsager, K., Easterling, D.R. 1999. Long-term trends in extreme precipitations events over the contermninous United States and Canada. Journal of Climate 12, 2515-2527. https://doi.org/10.1175/1520-0442(1999)012<2515:LTTIEP>2.0.CO;2.

Kuzuha, Y., Komatsu, Y., Tomosugi, K., Kishii, T. 2005. Regional flood frequency analysis, scaling and PUB. Journal of Japan Society of Hydrololy and Water Resources 18 (4), 441-458. http:// doi.org/10.3178/jjshwr.18.441.

Langousis, A., Veneziano, D., Furcolo, P., Lepore, C. 2009. Multifractal rainfall extremes: theoretical analysis and practical estimation. Chaos, Solitons and Fractals 39 (3), 1182-1194. https://doi.org/10.1016/j.chaos.2007.06.004.

Lovejoy, S., Schertzer, D. 1985. Generalized scale invariance in the atmosphere and fractal models of rain. Water Resources Research 21 (8), 1233-1250. https://doi.org/10.1029/ WR021i008p01233.

Mailhot, A., Duchesne, S., Caya, D., Talbot, G. 2007. Assessment of future change in intensityduration-frequency (IDF) curves for southern Quebec using the Canadian Regional Climate Model (CRCM). Journal of Hydrology 347, 197-210. https://doi.org/10.1016/j. jhydrol.2007.09.019.

Mauriño, M. 2004. Generalized rainfall-duration-frequency relationships: Applicability in different climatic regions of Argentina. Journal of Hydrologic Engineering 9 (4), 269-274. https://doi. org/10.1061/(ASCE) 1084-0699(2004)9:4(269).

Menabde, M., Seed, A., Pegram, G. 1999. A simple scaling model for extreme rainfall. Water Resources Research 35 (1), 335-339. https://doi.org/10.1029/1998WR900012.

Mongomery, D.C., Runger, G.C. 1996. Probabilidad y Estadística Aplicada a la Ingeniería. McGraw-Hill, Mexico, 995 pp.

Naghettini, M. 2012. Application of scale invariance properties of rainfall for estimating the intensity-duration-frequency relationships at Uberaba, in south-central Brazil. Aqua-LAC 4 (2), 45-60. http://unesdoc.unesco.org/images/0022/002270/227014m.pdf.

Nash, J. 2010. Directions for open source software over the next decade. Futures 42 (4), 427-433. https://doi.org/10.1016/j.futures.2009.11.027.

Nhat, L.M., Tachikawa, Y., Sayama, T., Takara, K. 2008. Development of regional rainfall intensity-duration frequency curves based on scaling properties. Annual Journal of Hydraulic Engineering, JSCE, 52, 85-90. http://doi.org/10.2208/prohe.52.85.

Overeem, A., Buishand, A., Holleman, I. 2008. Rainfall depth-duration-frequency curves and their uncertainties. Journal of Hydrology 348, 124-134. https://doi.org/10.1016/j. jhydrol.2007.09.044.

Paixao, E., Auld, H., Mirza, M.M.Q., Klaassen, J., Shephard, M. 2011. Regionalization of heavy rainfall to improve climatic design values for infrastructure: case study in Southern Ontario, Canada. Hydrological Sciences Journal 56 (7), 1067-1089. http://doi.org/10.1080/0262666 7.2011.608069.

Panthou, G., Vischel, T., Lebel, T., Quantin, G., Molinié, G. 2014. Characterizing the space-time structure of rainfall in the Sahel with a view to estimating IDF curves. Hydrology and Earth System Sciences 18, 5093-5107. https://doi.org/10.5194/hess-18-5093-2014.

Pappenberger, F., Beven K.J. 2006. Ignorance is bliss: Or seven reasons not to use uncertainty analysis. Water Resource Research 42 (5), W05302. http://doi.org/10.1029/2005WR004820.

Pavlopoulos, H., Gupta, V.K. 2003. Scale invariance of regional wet and dry duration of rain fields: a diagnostic study. Journal of Geophysical Research 108 (D8), 8387. https://doi. org/10.1029/2002JD002763.

Pettitt, A.N. 1979. A non-parametrical approach to the change-point problem. Applied Statistics 28 (2), 126-135. http://doi.org/10.2307/2346729. 
Puricelli, M. 2014. Actualización y análisis de las curvas intensidad - duración - frecuencia para la localidad de Balcarce, provincia de Buenos Aires, Argentina. Revista de Geología Aplicada a la Ingeniería y al Ambiente 32, 61-70. https://www.researchgate.net/publication/269993673_ Update_and_analysis_of_intensity_-_duration_-_frequency_curves_for_Balcarce_Buenos_ Aires_province_Argentina?ev=prf_high.

Robledo, F.A., Penalba, O. C. 2008. Análisis estacional de la frecuencia diaria y la intensidad de los extremos de precipitación sobre el sudeste de Sudamérica. Meteorológica 32-33 (1-2), 31-49. http://www.scielo.org.ar/pdf/meteoro/v32n1-2/v32n1-2a03.pdf .

Rodríguez-Iturbe, I., Rinaldo, A. 1997. Fractal river basins: Chance and self-organization. Cambridge University Press. 537 pp. https://www.amazon.com/Fractal-River-BasinsChance-Self-Organization/dp/0521004055\#reader_0521004055.

Rojas, A.E., Conde, A.A. 1985. Estimación del factor "R" de la Ecuación Universal de Pérdida de Suelos para el Centro-Este de la República Argentina. Ciencia del Suelo 3 (1-2), 85-94.

Schindewolf, M., Schmidt, J. 2012. Parameterization of the EROSION 2D/3D soil erosion model using a small-scale rainfall simulator and upstream runoff simulation. Catena 91, 47-55. https://doi.org/10.1016/j.catena.2011.01.007.

Scotta, E.S., Nani, L. A., Conde, A.A., Rojas, A.C., Castañeira, H., Papparotti, O.F. 1989. Manual de sistematización de tierras para control de la erosión hídrica y aguas superficiales excedentes ( $2^{\mathrm{a}}$ edición corregida y aumentada). Ediciones INTA. Serie Didáctica 17, 56 pp.

Sequeira, M. 2006. Determinación de la relación entre la intensidad, la duración y la frecuencia de las precipitaciones en Bahía Blanca. Actas de las IV Jornadas Interdisciplinarias del Sudoeste Bonaerense. Universidad Nacional del Sur. Bahía Blanca, Argentina, pp. 69-78.

Sivakumar, B. 2000. Fractal analysis of rainfall observed in two different climatic regions. Hydrological Sciences Journal 45 (5), 727-738. http://doi.org/10.1080/02626660009492373.

Sivapalan, M. 2003. Prediction in ungauged basins: a grand challenge for theoretical hydrology. Hydrological Processes 17, 3163-3170. http://doi.org/10.1002/hyp.5155.

Sivapalan, M., Blöschl, G. 1998. Transformation of point rainfall to areal rainfall: Intensityduration-frequency curves. Journal of Hydrology 204, 150-167. https://doi.org/10.1016/ S0022-1694(97)00117-0.

Szolgay, J., Parajka, J., Kohnová, S., Hlavčová, K. 2009. Comparison of mapping approaches of design annual maximum daily precipitation. Atmospheric Research 92 (3), 289-307. https:// doi.org/10.1016/j.atmosres.2009.01.009.

Travis, W.R. 2014. Weather and climate extremes: Pacemakers of adaptation? Water and Climate Extremes 5-6, 29-39. https://doi.org/10.1016/j.wace.2014.08.001.

USGS. 1982. Guidelines for determining flood flow frequency. Bulletin 17B of the Hydrology Subcommittee, Reston, 194 pp. https://water.usgs.gov/osw/bulletin17b/dl_flow.pdf.

Van de Vyver, H., Demarée, G.R. 2010. Construction of Intensity-Duration-Frequency (IDF) curves for precipitation at Lubumbashi, Congo, under the hypothesis of inadequate data. Hydrological Sciences Journal 55 (4), 555-564. http://doi.org/10.1080/02626661003747390.

Van Dijk, A.I.J.M., Bruijnzeel, L.A., Rosewell, C.J. 2002. Rainfall intensity-rainfall kinetic energy relationships: a critical literature appraisal. Journal of Hydrology 261 (1-4), 1-23. https://doi. org/10.1016/S0022-1694(02)00020-3.

Varela, C., Varni, M., Entraigas, I. 2003. Curvas intensidad-duración- frecuencia para diez años pluviográficos en la ciudad de Azul, centro de la provincia de Buenos Aires. Revista Argentina de Agrometeorología 3, 67-70. http://www.azul.bdh.org.ar/bdh3/archivos/ publications/555743/Modelo_de_transporte_de_solutos_en_aguas_subterraneas_de_la_ ciudad_de_Azul.pdf. 
Vidal, N.A.,Cousillas, C.F. 1982. Análisis de las precipitaciones del sudeste bonaerense. I: Período de retorno esperado para lluvias máximas. Editorial EUDEM, Universidad Nacional de Mar del Plata, Mar del Plata, 41 pp.

Vogel, R.M.2005. Regional calibration of watershed models. In: D.F. Frevert, V.P. Singh, Watershed Models. CRC Press, Boca Raton, pp.47-71. https://doi.org/10.1201/9781420037432.ch3.

Wood, S.N. 2011. Fast stable restricted maximum likelihood and marginal likelihood estimation of semiparametric generalized linear models. Journal of the Royal Statistical Society, Series B, Statistical Methodology 73 (1), 3-36. http://doi.org/10.1111/j.1467-9868.2010.00749.x.

Yevyevich, V. 1972. Probability and Statistics in Hydrology. Water Resources Publications, Fort Collins, Colorado, 50 pp.

Yu, P.S., Yang, T.C., Lin, C.S. 2004. Regional rainfall intensity formulas based on scaling property of rainfall. Journal of Hydrology 295 (1-4), 108-123. https://doi.org/10.1016/j. jhydrol.2004.03.003.

Zamanillo, E., Larenze, G., Tito, M.J., Perez, M., Garat, M.E. 2008. Tormentas de diseño para la provincia de Entre Ríos. Univ. Tecnológica Nacional, Buenos Aires. 108 pp.

Zhou, X., Persaud, N., Wang, H. 2006. Scale invariance of daily runoff time series in agricultural watersheds. Hydrology and Earth System Sciences 10 (1), 79-91. https://hal.archivesouvertes.fr/hal-00304818. 